Results of water-resources data-collection programs and interpretive hydrologic studies conducted by the U.S. Geological Survey (USGS) are published in reports and are made available to universities, State and local agencies, other Federal agencies, and the public. The following is a list of selected USGS reports on waterresources in Mississippi published since 1990 and categorized according to the major emphasis of the report; these reports are available for inspection at the Mississippi District Office in Jackson, Mississippi.

\section{GROUND-WATER REPORTS}

Arthur, J.K., 1994, Generalized description and analysis of groundwater flow in the Cockfield and Sparta aquifers in Hinds, Madison, and Rankin Counties, Mississippi: U.S. Geological Survey Water-Resources Investigations Report $93-4143,103$ p.

Arthur, J.K., and Taylor, R.E., 1990, Definition of the geohydrologic framework and preliminary simulation of ground-water flow in the Mississippi embayment aquifer system, Gulf Coastal Plain, United States: U.S. Geological Survey Water-Resources Investigations Report 86-4364, 97 p.

-1991 , Ground-water flow analysis of the Mississippi embayment aquifer system, south-central United States: U.S. Geological Survey Open-File Report 91-451, 105 .

Goldsmith, G.D.S., 1990, Potentiometricsurface map of the Gordo aquifer in northeastern Mississippi, August. through December 1987: U.S. Geological Survey Water-Resources Investigations Report 89-4060, 1 sheet.

-1991, Potentiometric-surface map of the Coffee Sand aquifer in northeastern Mississippi, August through December 1987: U.S. Geological Survey Water-Resources Investigations Report 91-4064, 1 sheet.

-1991, Potentiometric-surface map of the Eutaw-McShan aquifer in northeastern Mississippi, August through December 1987: U.S. Geological Survey Water-Resources Investigations Report 90-4157, 1 sheet.

-1993, Potentiometric-surface map, October through December $1988_{\mathrm{j}}$, and water-level change map, 1983-88, of the Mississippi River alluvial aquifer in northwestern Mississippi: U.S. Geological Survey Water-Resources Investigations Report 92-4176, 1 sheet.

Mallory, M.J., 1990, Evaluation of three scenarios of ground-water withdrawal from the Mississippi River alluvial aquifer in northwestern Mississippi: U.S. Geological Survey Open-File Report 90-103,17 p.

1993, Hydrogeology of the southeastern coastal plain aquifer system in parts of eastern Mississippi and western Alabama: U.S. Geological Survey Professional Paper $1410-\mathrm{G}, 57 \mathrm{p}$

Moreland, R.S., and O'Hara, C.G., 1994, Susceptibility of major aquifers to surface contamination - Holmes, Humphreys, Issaquena, Sharkey, Washington, and Yazoo Counties, Mississippi: U.S. Geological Survey Water-Resources Investigations Report 93-4129, 1 sheet.

Oakley, W. T, and Burt, D.E., Jr., 1992, Records of public-supply wells in Mississippi: U.S. Geological Survey Open-File Report $92-482,110 \mathrm{p}$.

-1994, Potentiometric-surface map of the Cockfield aquifer in Mississippi, October through November 1989: U.S. Geological Survey Water-Resources Investigations Report 93-4202, 1 sheet.

-1994, Potentiometric-surface map of the Meridian-upper Wilcox aquifer in Mississippi, October through December 1988: U.S. Geological Survey Water-Resources Investigations Report 94-4050, 1 sheet.

-1994, Potentiometric-surface map of the Sparta aquifer in Mississippi, October through December 1989:
U; S. Geological Survey Water-

Resources Investigations Report 94.4048 , I sheet.

-1994 , Potentiometric-surface map of the Winona-Tallahatta aquifer in northwestem Mississippi, November through December 1988: U.S. Geological Survey Water-Resources Investigations Report 94-4049, 1 sheet.

Oakley, W.T, Burt, D.E., Jr., and Goldsmith, G.D.S., 1994, Potentiometric-surface map of the lower Wilcox aquifer in Mississippi, October through December 1988: U.S. Geological Survey WaterResources Investigations Report 93-4174, 1 sheet

O'Hara, C.G., 1994, Permeability of soils in Mississippi: U.S. Geological Survey Water-Resources Investigations Report $94-4088,1$ sheet.

Rebich, R.A., 1993, A literature overview of methods to eyaluate and monitor Class I underground injection sites in Mississippi: U,S. Geological Survey Water-Resources Investigations Report $93-4058,60 \mathrm{p}$.

_ 1994, Data requirements for simulation of hydrogeologic effects of liquid waste injection, Harrison and Jackson Counties, Mississippi: U.S. Geological Survey Water-Resources Investigations Report 94-4021, 19 p.

Slack, L.J., and Darden, Daphne, 1991, Summary of aquifer tests in Mississippi, June 1942 through May 1988: U.S. Geological Survey WaterResources Investigations Report $90-4155,40 \mathrm{p}$.

\section{SURFACE-WATER REPORTS}

Floyd, P.C., 1993, Simulations of floodflows in the Magby Creek flood plain near Old Mill Road at Columbus, Mississippi: U.S. Geological Survey Water-Resources Investigations Report 93-4086, 39 p.

Landers, M.N., and Wilson, K.V., Jr., 1991, Flood characteristics of Mississippi streams: U.S. Geological Survey Water-Resources Investigations Report 91-4037, 82 p. 
Rebich, R.A., 1993, Preliminary summaries and trend analyses of stream discharge and sediment data for the Yazoo River Basin Demonstration Erosion Control Project, north-central Mississippi, July 1985 through September 1991: U.S. Geological Survey WaterResources Investigations Report 93-4068, $51 \mathrm{p}$.

Telis, P.A., 1991, Low-flow and flowduration characteristics of Mississippi streams: U.S. Geological Survey Water-Resources Investigations Report 90-4087, 214 p.

-1992, Techniques for estimating

7-day, 10-year low-flow characteristics for ungaged sites on streams in Mississippi: U.S. Geological Survey Water-Resources Investigations Report 91-4130, 143 p.

Turnipseed, D.P., 1993, Lateral movement and stability of channel banks near two highway crossings in the Pascagoula River Basin in Mississippi: U.S. Geological Survey Water-Resources Investigations Report 93-4131, 24 p.

-1994, Lateral movement and stability of channel banks near four highway crossings in southwestern Mississippi: U.S. Geological Survey Water-Resources Investigations Report 94-4035, 33 p.

Turnipseed, D.P., and Baldwin, W.T., 1992, Channel and bank stability of Bakers Creek at State Highway 547 near Port Gibson, Claiborne County, Mississippi: U.S. Geological Survey Open-File Report 92-636, 15 p.

Turnipseed, D.P., and Wilson, K.V., Jr., 1990, Channel and bank stability of Twentymile Creek at U.S. Highway 45 near Wheeler, Prentiss County, Mississippi: U.S. Geological Survey Open-File Report 90-111, 16 p.

-1992, Channel and bank stability of Standing Pine Creek at State Highway 488 near Freeny, Leake County, Mississippi: U.S. Geological Survey Open-File Report 92-112, 18 p.

Wilson, K.V., Jr., and Landers, M.N., 1991, Annual peak stages and discharges for streamflow-gaging stations in Mississippi: U.S. Geological Survey Water-Resources Investigations Report 91-4098, 705 p.
Wilson, K.V., Jr., and Turnipseed, D.P., 1990, Channel and bank stability of Wolf Creek and a tributary at U.S. Highway 45 near Wheeler, Prentiss County, Mississippi: U.S. Geological Survey Open-File Report 90-110, $18 \mathrm{p}$.

-1993, Channel-bed and channelbank stability of Standing Pine Creek tributary at State Highway 488 at Free Trade, Leake County, Mississippi: U.S. Geological Survey Open-File Report 93-37, 20 p.

1994, Geomorphic response to channel modifications of Skuna River at the State Highway 9 crossing at Bruce, Calhoun County, Mississippi: U.S. Geological Survey WaterResources Investigations Report 94-4000, 43 p.

\section{WATER-QUALITY REPORTS}

Kalkhoff, S.J., 1993, Brine contamination of ground water and streams in the Baxterville oil field area, Lamar and Marion Counties, Mississippi: U.S. Geological Survey Water-Resources Investigations Report 93-4147, 37 p.

Mallory, M.J., 1994, National WaterQuality Assessment Program-The Mississippi Embayment: U.S. Geological Survey Fact Sheet 94-047, 2 p.

Slack, L.J., 1992, Water-quality and bottom-material chemistry data for the Yazoo River Basin Demonstration Erosion Control Project, north-central Mississippi, February 1988September 1991: U.S. Geological Survey Open-File Report 92-469, $197 \mathrm{p}$.

Slack, L.J., and Grantham, P.E., 1991, Quality of water in the upper Yazoo River and Steele Bayou Basins, northwestern Mississippi, March 1990 through February 1991: U.S. Geological Survey Open-File Report 91-509, $46 \mathrm{p}$.

Slack, L.J., and Oakley, W.T., 1989, Tritium analyses of shallow ground water in Mississippi, April 1989: U.S. Geological Survey Open-File Report $89-418,8 \mathrm{p}$.

1991, Tritium in ground water in Mississippi, 1989-90: U.S. Geological Survey Open-File Report 91-177, 12 p.
1992, Tritium analyses of water in the Mississippi River alluvial aquifer in northwestern Mississippi, August 1991: U.S. Geological Survey OpenFile Report 92-75, 9 p.

Slack, L.J., Oakley, W.T., and Cooper, L.M., 1993, Quality of ground water in Jackson County, Mississippi, March-June 1993: U.S. Geological Survey Open-File Report 93-479, $38 \mathrm{p}$.

Slack, L.J., Oakley, W.T., O'Hara, C.G., and Cooper, L.M., 1994, Quality of ground water in Harrison County, Mississippi, June-July 1993: U.S. Geological Survey Open-File Report 94-125, 33 p.

\section{WATER-USE REPORTS}

Barber, N.L., 1991, Water withdrawals in the Black Warrior-Tombigbee Basin and Alcorn County, Mississippi, 1985-87: U.S. Geological Survey Water-Resources Investigations Report 90-4061, 42 p.

Callahan, J.A., and Barber, N.L., 1990, Freshwater use in Mississippi, 1985: U.S. Geological Survey WaterResources Investigations Report 88-4229, 1 sheet.

Johnson, P.M., 1994, Total water withdrawals in Mississippi, 1990: U.S. Geological Survey Open-File Report 93-375, 67 p. -1994, Estimated water withdrawals in Mississippi during 1990: U.S. Geological Survey Fact Sheet $94-060,2$ p.

\section{OTHER REPORTS}

Moss, C.P., 1994, Water resources activities of the Mississippi District, 1993-94: U.S. Geological Survey Open-File Report 94-452, 24 p.

Slack, L.J., 1991, Quality-assurance plan for water-resources activities of the U.S. Geological Survey in Mississippi -1991: U.S. Geological Survey Open-File Report 91-526, 47 p.

\section{Carol P. Moss}

For additional information contact:

U.S. Geological Survey

100 W. Capitol St., Suite 710

Jackson, Mississippi 39269

(601) $965-4600$ 